\title{
Fungsi Adrenal pada Sepsis di Unit Perawatan Intensif Pediatrik
}

\author{
R. Irma Rachmawati, Dwi Putro Widodo, Bambang Tridjaja AAP, Antonius H. Pudjiadi \\ Departemen Ilmu Kesehatan Anak, Fakultas Kedokteran Universitas Indonesia- Rumah Sakit Cipto \\ Mangunkusumo, Jakarta
}

Latar belakang. Insufisiensi adrenal sering dijumpai pada pasien syok septik dan berhubungan dengan kejadian syok refrakter katekolamin dan peningkatan mortalitas.

Tujuan. Mengetahui profil fungsi adrenal pada anak yang menderita sepsis di Unit Perawatan Intensif Pediatrik RSCM.

Metode. Penelitian deskriptif dengan desain potong lintang. Semua subjek menjalani uji stimulasi kortikotropin dosis standar. Insufisiensi adrenal (IA) ditegakkan jika respons peningkatan kortisol terhadap uji $(\Delta$ maks $) \leq 9 \mu \mathrm{g} / \mathrm{dl}$ dan dikelompokkan menjadi absolut (IAA) jika kortisol pra-uji $\mathrm{t}_{0}<20 \mu \mathrm{g} / \mathrm{dl}$ dan relatif (IAR) jika $t_{0} \geq 20 \mu \mathrm{g} / \mathrm{dl}$.

Hasil. Tiga puluh anak sepsis (18 laki-laki) diikutsertakan dalam penelitian. usia median adalah 29 (1-153) bulan dan median skor PELOD 12,5 (0-33). Insufisiensi adrenal dijumpai pada 8 (26,7\%) pasien (2 IAA and 6 IAR), lebih sering pada perempuan $(p=0,003)$, serta cenderung lebih sering pada syok septik $(p=0,682)$. Median $\mathrm{t}_{0} 32,75(4,23-378) \mu \mathrm{g} / \mathrm{dl}, \mathrm{t}_{30-60} 48,20(16,70-387) \mu \mathrm{g} / \mathrm{dl}$, dan $\Delta$ maks $15,40(0,90-60,80) \mu \mathrm{g} /$ dl. Kadar $t_{0}$ dan $t_{30-60}$ lebih tinggi pada kelompok syok septik ( $p=0,03$ dan $\left.p=0,01\right)$ namun tidak berbeda antara subjek dengan dan tanpa IA. Terdapat kecenderungan korelasi positif antara skor PELOD dengan $\mathrm{t}_{0}$ dan $\mathrm{t}_{30-60}(\mathrm{r}=0,7$; dan $\mathrm{r}=0,6 ; p \leq 0,001)$. Hipotensi sistolik dijumpai pada seluruh subjek dengan IA dan syok refrakter katekolamin cenderung lebih sering pada kelompok IA $(p=0,67)$. Mortalitas 36,7\%, tidak berbeda antara subjek dengan dan tanpa IA.

Kesimpulan. Insufisiensi adrenal sering dijumpai pada yang menderita anak sepsis dan harus dipertimbangkan pada kondisi syok septik. Penelitian lanjutan diperlukan untuk menentukan efektivitas terapi steroid.

Sari Pediatri 2011;12(6):426-32.

Kata kunci: insufisiensi adrenal, sepsis, syok septik, kortisol

Alamat korespondensi:

Dr. Antonius H. Pudjiadi, Sp.A(K). Divisi Pediatri Gawat Darurat, Departemen Ilmu Kesehatan Anak FKUI-RSCM, Jl. Salemba No. 6 Jakarta 10430. Telp/Fax. 021-3914126 E-mail: antonicu@cbn.net.id
1 ktivasi jaras hipotalamus-hipofisis-adrenal 4 (HHA) sangat penting dalam memelihara dan mempertahankan homeostasis sel mausepsis. ${ }^{1-3}$ Glukokortikoid sebagai hasil akhir aktivasi 
jaras HHA memelihara homeostasis tubuh dengan cara memodulasi respons imun, proses metabolisme, dan sistem kardiovaskular. ${ }^{1}$

Akhir-akhir ini insufisiensi adrenal dilaporkan cukup sering pada pasien kritis seperti sepsis berat dan syok septik dengan insidens 15\%-61\%.4-16 Kondisi tersebut bersifat sementara dan akan kembali normal dengan membaiknya sepsis sehingga diduga mediator inflamasi yang dilepaskan selama syok septik menyebabkan disfungsi jaras HHA dan insufisiensi adrenal. ${ }^{17,18}$ Hingga saat ini belum ada kesepakatan mengenai kadar kortisol yang dianggap adekuat sebagai respons terhadap stres, selain itu penelitian pada populasi pediatrikpun masih terbatas. Berbagai penelitian ${ }^{4-16}$ melaporkan adanya hubungan kuat antara insufisiensi adrenal dengan syok refrakter katekolamin sehingga diduga insufisiensi adrenal merupakan salah satu penyebab masih tingginya mortalitas pada sepsis. Penelitian bertujuan mengetahui profil fungsi adrenal pada anak sepsis sebagai salah satu upaya menurunkan morbiditas dan mortalitas akibat sepsis.

\section{Metode}

Penelitian merupakan penelitian deskriptif dengan desain potong lintang yang dilaksanakan di Unit Perawatan Intensif Pediatrik RSCM Jakarta sejak November 2009 hingga Mei 2010. Subjek adalah anak berusia 1 bulan-<18 tahun dengan diagnosis sepsis, diambil secara konsekutif. Sepsis ditegakkan jika pasien memenuhi kriteria systemic inflammatory respons syndrome (SIRS) sesuai konsensus internasional sepsis pediatrik $^{19}$ disertai bukti infeksi berupa hasil biakan positif atau kadar prokalsitonin $\geq 2 \mathrm{ng} / \mathrm{ml}$. Pasien yang sedang atau pernah mendapat terapi kortikosteroid jangka panjang dalam enam bulan terakhir, menderita kelainan adrenal, hipotalamus, hipofisis, kelainan kongenital, sindrom, pasca-bedah otak, atau HIV tidak diikutsertakan dalam penelitian. Penelitian ini telah mendapat persetujuan etik penelitian dari Komite Etik Penelitian Fakultas Kedokteran Universitas Indonesia dan semua orangtua subjek telah menandatangani informed consent.

Karakteristik dasar meliputi umur, jenis kelamin, diagnosis penyakit dasar, skor PELOD, serta karakteristik klinis dan laboratoris dicatat, termasuk kejadian syok refrakter katekolamin. Syok tergantung/ refrakter katekolamin didefinisikan jika diperlukan dopamin $>10 \mu \mathrm{g} / \mathrm{kg} /$ menit atau epinefrin/norepinefrin dosis berapapun selama $>24$ jam, untuk mempertahankan perfusi yang baik dan tekanan darah normal berdasarkan usia. Bahkan jika perfusi perifer tetap buruk dan tekanan darah tetap rendah $(<\mathrm{P} 5$ berdasarkan usia) meskipun dengan pemberian epinefrin atau norepinefrin. ${ }^{14,20,21}$ Semua subjek menjalani uji stimulasi kortikotropin dosis standar menggunakan ACTH sintetik intramuskular (Synacthen ${ }^{\circledR}$ Depot; $N o$ vartis Pharmaceuticals, Jerman) dalam 24 jam setelah masuk penelitian. Dosis Synacthen ${ }^{\circledR}$ untuk usia $>2$ tahun $250 \mu \mathrm{g}$ dan $\leq 2$ tahun $125 \mu \mathrm{g} .{ }^{11,22}$ Darah beku 2-3 $\mathrm{ml}(0,3-0,5 \mathrm{ml}$ serum) diambil untuk pengukuran kadar kortisol pra-uji $\left(\mathrm{t}_{0}\right)$ dan 30-60 menit pasca-uji $\left(\mathrm{t}_{30-60}\right) .{ }^{13,14}$ Respons peningkatan kortisol terhadap uji $\left(\Delta\right.$ maks) diperoleh dari selisih antara $\mathrm{t}_{30-60}$ dengan $\mathrm{t}_{0} \cdot{ }^{13,14}$ Spesimen dalam bentuk serum memiliki stabilitas selama tujuh hari jika disimpan dalam suhu $2-8^{\circ}$ C. Pengukuran kadar kortisol menggunakan metode immunochemiluminescent, alat Immulite 2000, dan reagen DPC/ Immulite (Los Angeles, CA), dengan kisaran pengukuran antara $1-50 \mu \mathrm{g} / \mathrm{dl}$, sensitivitas analisis minimal $0,2 \mu \mathrm{g} / \mathrm{dl}$, dan koefisien variasi $10 \%$.

Insufisiensi adrenal ditegakkan jika $\Delta$ maks $\leq 9 \mu \mathrm{g} /$ dldan lebih lanjut dikelompokkan menjadi insufisiensi adrenal absolut (IAA) jika $\mathrm{t}_{0}<20 \mu \mathrm{g} / \mathrm{dl}$ dan relatif (IAR) jika $\mathrm{t}_{0} \geq 20 \mu \mathrm{g} / \mathrm{dl}$. Respons adrenal adekuat jika $\Delta$ maks $>9 \mu \mathrm{g} / \mathrm{dl}$ dan dikelompokkan menjadi respons adekuat disertai peningkatan $\mathrm{t}_{0} \geq 20 \mu \mathrm{g} / \mathrm{dl}$ dan tanpa peningkatan $\mathrm{t}_{0}\left(\mathrm{t}_{0}<20 \mu \mathrm{g} / \mathrm{dl}\right) .{ }^{13}$ Data dianalisis menggunakan program SPSS versi 12.0. Karakteristik subjek disajikan dalam proporsi, rerata (standar deviasi) atau median (minimum-maksimum). Perbedaan proporsi antara dua kelompok dianalisis dengan uji chi square atau uji mutlak Fisher, perbedaan rerata dianalisis dengan student t-test atau Mann-Whitney, dan korelasi antara dua variabel numerik dianalisis dengan uji korelasi Pearson. Nilai $\mathrm{p}<0,05$ bermakna secara statistik.

\section{Hasil}

Selama periode penelitian terdapat 48 anak dengan sepsis yang memenuhi kriteria inklusi penelitian, 16 subjek dieksklusi, 2 spesimen darah lisis, sehingga total terdapat 30 subjek yang direkrut dan dianalisis dalam penelitian (Gambar 1). Median (rentang) usia subjek 29 bulan (1-153 bulan) dengan median skor 
PELOD 12.5 (0-33). Median prokalsitonin 48,14 $(0,22-1583,92) \mathrm{ng} / \mathrm{ml}$ (Tabel 1). Penyakit kronik dijumpai pada 12 (40\%) subjek dan yang terbanyak adalah penyakit hati kronik (6 dari 12 subjek). Sembilan $(30 \%)$ subjek merupakan pasien pascaoperasi. Fokus infeksi terbanyak adalah saluran cerna/ intra-abdominal $(66,7 \%)$, saluran napas $(46,7 \%)$, dan saluran kemih $(33,3 \%)$.

Terdapat 8 subjek (26,7\%; IK 95\% 10,9-42,5\%) yang mengalami insufisiensi adrenal, terdiri dari 2 $(6,7 \%)$ IAA dan 6 (20\%) IAR (Gambar 1). Proporsi insufisiensi adrenal cenderung lebih tinggi pada subjek dengan syok septik (6/20 vs $2 / 10, p=0,682)$. Pada Tabel 2 tertera proporsi insufisiensi adrenal pada populasi penelitian berdasarkan berbagai kriteria yang diajukan pada beberapa penelitian yang telah dipublikasikan sebelumnya.

Insufisiensi adrenal lebih sering dijumpai pada anak perempuan dan cenderung pada anak yang lebih tua. Hipotensi sistolik dijumpai pada seluruh subjek dengan insufisiensi adrenal dan syok tergantung/ refrakter katekolamin cenderung lebih sering pada kelompok tersebut. Mortalitas 36,7\% dengan case fatality rate insufisiensi adrenal $50 \%$, namun tidak ada perbedaan mortalitas yang bermakna antara kelompok dengan dan tanpa insufisiensi adrenal (Tabel 1).

Kadar kortisol subjek tertera pada Tabel 3. Median kortisol pra- dan pasca-uji lebih tinggi pada kelompok syok septik [ $\mathrm{t}_{0} 41,9(5,06-378,0) \mu \mathrm{g} / \mathrm{dl}$ vs $20,4(4,23-$ $67,7) \mu \mathrm{g} / \mathrm{dl}, \mathrm{p}=0,03$ dan $\mathrm{t}_{30-60} 58,5(16,7-387,0) \mu \mathrm{g} /$ $\mathrm{dl}$ vs $39,25(23,8-77,0) \mu \mathrm{g} / \mathrm{dl}, \mathrm{p}=0,01)$, sedangkan median $\Delta$ maks tidak berbeda antara kedua kelompok tersebut $[17,65(0,9-60,8) \mu \mathrm{g} / \mathrm{dl}$ vs $14,0(4,7-21,98)$ $\mu \mathrm{g} / \mathrm{dl}, \mathrm{p}=0,59]$. Lebih lanjut, terdapat kecenderungan korelasi positif antara skor PELOD dengan kadar kortisol pra- dan pasca-uji ( $r=0,7$ dan $r=0,6 ; p \leq 0,001)$ dan korelasi negatif lemah dengan $\Delta$ maks $(r=-0,2$; $\mathrm{p}=0,344$ ).

Median kortisol pra-uji pada kelompok subjek dengan insufisiensi adrenal cenderung lebih tinggi daripada kelompok subjek tanpa insufisiensi adrenal sedangkan median $\Delta$ maks lebih rendah

48 pasien anak memenuhi kriteria inklusi penelitian

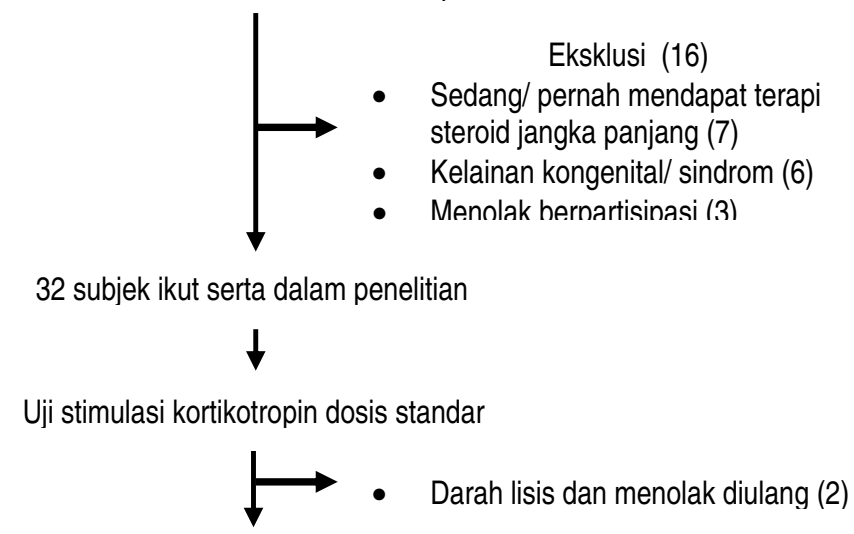

Total 30 subjek direkrut dan dianalisis dalam penelitian

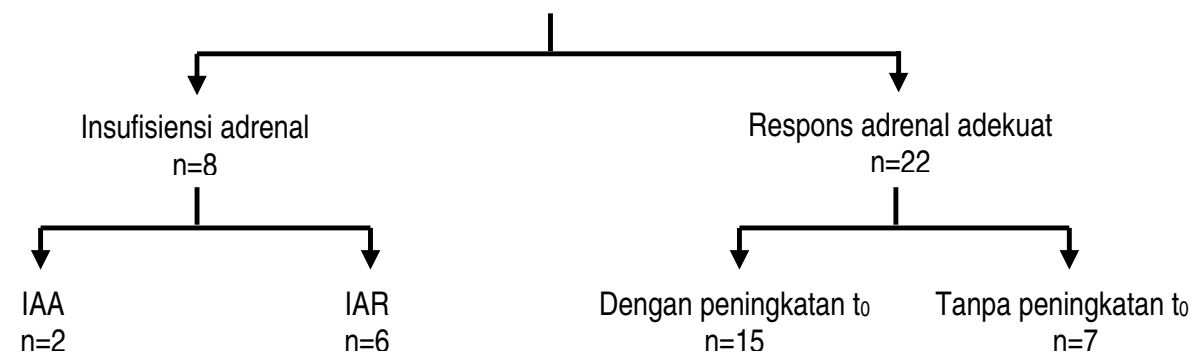

Gambar 1. Alur subjek penelitian

Keterangan: IAA=insufisiensi adrenal absolut; IAR=insufisiensi adrenal relatif; t $0=$ kadar kortisol pra-uji. 
R. Irma Rachmawati dkk: Fungsi adrenal pada sepsis di unit perawatan intensif pediatrik

Tabel 1. Karakteristik subjek penelitian secara keseluruhan dan berdasarkan kelompok fungsi adrenal

\begin{tabular}{|c|c|c|c|c|}
\hline \multirow[t]{2}{*}{ Variabel } & \multirow{2}{*}{$\begin{array}{l}\text { Total } \\
\mathrm{n}=30\end{array}$} & \multicolumn{2}{|c|}{ Insufisiensi Adrenal } & \multirow[t]{2}{*}{ Nilai p } \\
\hline & & $\mathrm{Ya}(\mathrm{n}=8)$ & Tidak $(n=22)$ & \\
\hline Usia (bulan) & $29(1-153)$ & $101(2-153)$ & $20(1-151)$ & 0,15 \\
\hline Jenis kelamin $(\mathrm{P}: \mathrm{L})$ & $12: 18$ & $7: 1$ & $5: 17$ & $0,003^{*}$ \\
\hline Hipotensi sistolik & $27(90)$ & 8 & 19 & 0,54 \\
\hline Syok septik & $20(66,7)$ & 6 & 14 & 0,68 \\
\hline $\begin{array}{l}\text { Syok septik tergantung/ refrakter } \\
\text { katekolamin }\end{array}$ & $9(30)$ & 3 & 6 & 0,67 \\
\hline Ventilasi mekanik & $15(50)$ & 4 & 11 & 1,00 \\
\hline Acute lung injury/ARD & $20(66,7)$ & 7 & 13 & 0,34 \\
\hline Skor PELOD & $12,5(0-33)$ & $17(1-33)$ & $12(0-32)$ & 0,34 \\
\hline Hitung leukosit $(/ \mu \mathrm{l})$, rerata $(\mathrm{SB})$ & $15450(500-55400)$ & $12.800(500-40400)$ & $15450(3500-55400)$ & 0,5 \\
\hline $\begin{array}{l}\text { Glukosa darah sewaktu }(\mathrm{mg} / \mathrm{dl}) \text {, } \\
\text { rerata }(\mathrm{SB})\end{array}$ & $103(13-469)$ & $112(13-140)$ & $102(24-469)$ & 0,71 \\
\hline Hipoglikemia, n (\%) & $5(16,7)$ & 1 & 4 & 1,00 \\
\hline Natrium $(\mathrm{mEq} / \mathrm{l})$, rerata $(\mathrm{SB})$ & $131,76(6,12)$ & $131,5(6,72)$ & $131,86(6,06)$ & 0,98 \\
\hline Hiponatremia, n (\%) & $10(33,3)$ & 3 & 7 & 1,00 \\
\hline Kalium $(\mathrm{mEq} / \mathrm{l})$, rerata $(\mathrm{SB})$ & $3,70(1,01)$ & $4,15(0,52)$ & $3,54(1,11)$ & 0,08 \\
\hline Hiperkalemia, n (\%) & $2(6,7)$ & 0 & 2 & 1,00 \\
\hline Lama rawat (hari), n (SB) & $7(0,3-30,0)$ & $10,5(0,25-25)$ & $6,5(1,5-30)$ & 0,72 \\
\hline Meninggal, n (\%) & $11(36,7)$ & 4 & 7 & 0,42 \\
\hline
\end{tabular}

Variabel numerik yang berdistribusi normal disajikan dalam rerata (simpang baku) dan yang tidak normal disajikan dalam median (minimummaksimum). Variabel kategorik disajikan dalam n (\%). †Satu orang subjek dapat memiliki lebih dari 1 fokus infeksi.

Tabel 2. Proporsi insufisiensi adrenal menurut berbagai definisi

\begin{tabular}{|c|c|c|c|c|}
\hline \multirow{2}{*}{ Peneliti (tahun) } & \multirow{2}{*}{ Populasi } & Definisi Insufisiensi Adrenal & \multicolumn{2}{|c|}{ Insidens insufisiensi adrenal } \\
\hline & & Kadar kortisol $(\mu \mathrm{g} / \mathrm{dl})$ & Literatur (\%) & Penelitian ini (\%) \\
\hline Rothwell $\mathrm{dkk}^{5}$ (1991) & Dewasa & $\Delta$ maks $<9$ & 40 & 23,3 \\
\hline Soni $\mathrm{dkk}^{6}(1995)$ & Dewasa & Kortisol pasca-uji stimulasi $<18$ & 24 & 3,3 \\
\hline Hatherill dkk (1999) & Anak & $\Delta$ maks $<7$ & 52 & 20 \\
\hline Marik \& Zaloga ${ }^{12}(2001)$ & Dewasa & Kortisol pra-uji $<25$ dan pasca-uji $<25$ & 61 & 6,7 \\
\hline Loisa $\mathrm{dkk}^{9}(2002)$ & Dewasa & Kortisol pra-uji $<25$ dan $\Delta$ maks $\leq 9$ & 15 & 10 \\
\hline Menon \& Clarson ${ }^{11}$ (2002) & Anak & Kortisol pra-uji $<7$ atau pasca-uji $<18$ & 31 & 10 \\
\hline Pizarro $\mathrm{dkk}^{13}(2005)$ & Anak & $\Delta$ maks $\leq 9$ & 44 & 26,7 \\
\hline Sarthi dkk ${ }^{14}(2007)$ & Anak & $\Delta$ maks $<9$ & 30 & 23,3 \\
\hline Hebbar dkk ${ }^{4}$ (2009) & Anak & Kortisol basal $<25$ & 58 & 40 \\
\hline Menon dkk ${ }^{16}(2010)$ & Anak & $\Delta$ maks $<9$ & 30,2 & 23,3 \\
\hline
\end{tabular}

$\Delta$ maks=respons peningkatan kortisol terhadap uji stimulasi kortikotropin.

Tabel 3. Kadar kortisol subjek berdasarkan kelompok fungsi adrenal

\begin{tabular}{lcccc}
\hline Variabel & Total & \multicolumn{2}{c}{ Insufisiensi adrenal } & Nilai $\mathrm{p}$ \\
\cline { 3 - 4 } & $(\mathrm{n}=30)$ & Ya $(\mathrm{n}=8)$ & Tidak $(\mathrm{n}=22)$ & \\
\hline Kortisol pra-uji $\left(\mathrm{t}_{0}\right)$ & $32,75(4,23-378,00)$ & $42,30(9,68-378,00)$ & $32,00(4,23-179,00)$ & 0,56 \\
Kortisol pasca-uji $\left(\mathrm{t}_{30-60}\right)$ & $48,20(16,70-387,00)$ & $46,80(16,70-387,00)$ & $49,85(26,00-197,00)$ & 0,37 \\
$\Delta$ maks & $15,40(0,90-60,80)$ & $5,35(0,90-9,00)$ & $18,75(9,20-60,80)$ & $0,00^{*}$ \\
\hline
\end{tabular}

Kadar kortisol dalam $\mu \mathrm{g} / \mathrm{dl}$ dan disajikan dalam median (mínimum-maksimum).

$\Delta$ maks=respons peningkatan kortisol terhadap uji stimulasi kortikotropin.

${ }^{*} \mathrm{p}<0,05$ secara statistik bermakna 
pada kelompok subjek dengan insufisiensi adrenal (Tabel 3). Median kortisol pra- dan pasca-uji juga lebih tinggi pada kelompok subjek yang meninggal [ $\mathrm{t}_{0} 52,7(21,5-378,0) \mu \mathrm{g} / \mathrm{dl}$ vs $21,3(4,2-133,0) \mu \mathrm{g} /$ $\mathrm{dl} ; \mathrm{p}=0,005$ dan $\mathrm{t}_{30-60} 71,3(30,1-387,0) \mu \mathrm{g} / \mathrm{dl}$ vs $40,5(16,7-153,0) \mu \mathrm{g} / \mathrm{dl} ; \mathrm{p}=0,01]$ namun tidak ada perbedaan untuk $\Delta$ maks.

\section{Pembahasan}

Hasil penelitian menunjukkan bahwa insufisiensi adrenal cukup banyak dijumpai pada anak dengan sepsis, khususnya syok septik. Berbagai kriteria telah diajukan namun hingga saat ini belum ada kriteria yang dapat diterima secara umum. Dengan menggunakan berbagai kriteria tersebut, angka kejadian insufisiensi adrenal pada penelitian kami bervariasi antara 3,3\%$40 \%$. Variasi besar sampel, desain penelitian, karakteristik subjek, kriteria inklusi dan eksklusi, serta kriteria diagnostik menyebabkan perbandingan hasil tersebut menjadi tidak mudah. Kriteria respons peningkatan kortisol terhadap uji stimulasi kortikotropin $(\Delta$ maks) $\leq 9 \mu \mathrm{g} / \mathrm{dl}$ yang digunakan pada penelitian ini merupakan kriteria yang paling sering digunakan dan yang saat ini dilaporkan dapat menggambarkan hubungan antara ketidakmampuan adrenal berespons terhadap uji stimulasi dengan dampak klinis khususnya syok refrakter katekolamin. Berdasarkan kriteria tersebut, terdapat 26,7\% (IK 95\% 10,9-42,25\%) yang mengalami insufisiensi adrenal (6 IAA dan 2 IAR) dan proporsi tersebut cenderung lebih besar pada kelompok subjek yang mengalami syok septik.

Penelitian kami menggunakan uji stimulasi kortikotropin dosis standar $(250 \mu \mathrm{g})$ karena meskipun dosis tersebut 100 kali lebih tinggi dari kadar ACTH normal yang diinduksi oleh stres (suprafisiologis) ${ }^{23}$ dan dosis rendah $(1 \mu \mathrm{g})$ dilaporkan memiliki sensitivitas dan spesifisitas yang cukup baik, ${ }^{16,24-26}$ namun uji dengan dosis rendah masih memerlukan validasi lebih lanjut dan belum dianjurkan untuk digunakan secara luas. $^{27}$

Penelitian kami dan juga penelitian sebelumnya, ${ }^{4,7,10,14}$ mendapatkan peningkatan kadar kortisol pra-uji. Peningkatan kadar kortisol pra-uji (random cortisol) menunjukkan masih ada respons awal jaras HHA yang adekuat dalam menghadapi stres. ${ }^{28}$ Namun demikian, temuan insidens insufisiensi adrenal yang cukup tinggi serta kecenderungan kadar kortisol pra-uji yang lebih tinggi pada kelompok subjek yang mengalami insufisiensi adrenal pada penelitian ini, seperti halnya pada penelitian Menon dkk. ${ }^{16}$ Terdapat respons awal yang adekuat, namun sejumlah pasien tidak mampu memberikan respons peningkatan kortisol lebih lanjut yang adekuat terhadap derajat penyakit yang sedang dihadapi. Hal tersebut dapat disebabkan tidak adanya cadangan adrenal, ketidakmampuan kelenjar adrenal mempertahankan peningkatan kortisol pada keadaan syok persisten akibat jaras HHA yang sudah terstimulasi maksimal (adrenal exhaustion syndrome). Kemungkinan juga karena terdapat gangguan integritas HHA lebih lanjut akibat pelepasan sitokin yang berlebihan dan berkepanjangan pada syok septik. ${ }^{2,27-30}$ Kadar kortisol pra-uji yang tinggi juga mungkin disebabkan resistensi glukokortikoid di jaringan perifer akibat penurunan jumlah serta gangguan fungsi dan afinitas reseptor glukokortikoid di perifer oleh sitokin yang dilepaskan selama sepsis. 1,2,31,32 Namun demikian fenomena yang khususnya dijumpai pada IAR belum dapat dibuktikan pada penelitian kami.

Nilai median kadar kortisol pra-uji juga dijumpai lebih tinggi pada kelompok subjek dengan syok septik, seperti halnya pada penelitian Sarthi $\mathrm{dkk}^{14}$ dan juga Annanne dkk. ${ }^{28}$ Fenomena tersebut mendukung teori bahwa derajat aktivasi awal jaras HHA dan peningkatan kadar kortisol dalam darah sebanding dengan derajat stres yang dialami oleh tubuh. ${ }^{2}$ Temuan penting lain yang dapat mendukung teori tersebut adalah adanya korelasi positif antara skor PELOD yang menggambarkan derajat disfungsi organ dengan kadar kortisol pra-uji serta dijumpainya fenomena median kadar kortisol pra-uji yang secara bermakna lebih tinggi pada kelompok subjek yang meninggal. Jurney dkk serta Wade dkk seperti yang dikutip oleh Marik dan Zaloga ${ }^{2}$ melaporkan pada pasien kritis terdapat peningkatan kadar kortisol dan kadar tertinggi terdapat pada pasien dengan skor derajat penyakit dan mortalitas yang paling tinggi. Sedangkan Hebbar $\mathrm{dkk}^{4}$ melaporkan kadar kortisol basal baik pada pasien anak dengan maupun tanpa sepsis tidak berkorelasi dengan skor PELOD maupun PRISM III.

Meskipun tidak ada perbedaan yang bermakna, kelompok subjek dengan dan tanpa insufisiensi adrenal menunjukkan nilai median kortisol pasca-uji yang tinggi $(>18 \mu \mathrm{g} / \mathrm{dl})$. Dengan demikian kriteria insufisiensi adrenal klasik yaitu kadar kortisol puncak pasca-uji $<18 \mu \mathrm{g} / \mathrm{dl}^{6,10,11}$ sepertinya tidak dapat digunakan pada populasi penelitian kami dan kriteria 
$\Delta$ maks lebih sesuai untuk mendeteksi insufisiensi adrenal pada sepsis, khususnya IAR. Kondisi tersebut bersifat sementara dan akan membaik setelah sepsis teratasi.

Meskipun perbedaan tidak bermakna, insufisiensi adrenal cenderung terjadi pada anak dengan usia yang lebih besar seperti yang dilaporkan pada beberapa penelitian sebelumnya. ${ }^{7,13,16}$ Perempuan lebih sering mengalami insufisiensi adrenal. Belum ada penjelasan pasti mengenai fenomena tersebut. Insidens sepsis dilaporkan menurun seiring dengan bertambahnya usia anak, ${ }^{33}$ sedangkan jenis kelamin pada penelitian lain tidak pernah dilaporkan berbeda antara subjek dengan maupun tanpa insufisiensi adrenal. ${ }^{7,14-16}$

Hipotensi dijumpai pada seluruh subjek dengan insufisiensi adrenal dan syok tergantung/refrakter katekolamin cenderung lebih sering dijumpai. Berbagai penelitian melaporkan insidens syok refrakter katekolamin lebih tinggi pada anak dengan insufisiensi adrenal dan mereka memerlukan dosis vasopresor yang lebih tinggi dan lebih sering memerlukan epinefrin atau norepinefrin untuk stabilisasi hemodinamik (OR 6,1; IK 95\% 1,2-30,1). ${ }^{7,13,14}$ Annane $\mathrm{dkk}^{28}$ menyimpulkan bahwa penurunan cadangan fungsi adrenal pada syok septik dapat menurunkan sensitivitas terhadap noradrenalin.

Mortalitas pada penelitian kami cukup tinggi $(36,7 \%)$ dengan case fatality rate insufisiensi adrenal $50 \%$. Meskipun tidak terdapat hubungan yang bermakna, mortalitas cenderung lebih besar pada kelompok subjek dengan insufisiensi adrenal. Dengan besar sampel yang relatif kecil, penelitian kami tidak cukup kuat untuk mendeteksi perbedaan mortalitas antara kedua kelompok tersebut sehingga hal ini menjadi keterbatasan penelitian. Selain itu, kemungkinan terdapat faktor lain yang berperan menentukan mortalitas pada sepsis pediatrik. Pada penelitian kami skor PELOD tinggi, syok septik tergantung/refrakter katekolamin, serta ALI/ARDS secara bermakna berhubungan dengan mortalitas (data tidak disajikan).

Besar sampel memiliki konsekuensi presisi insidens insufisiensi adrenal yang cukup lebar pada populasi (IK 95\%: 10,9\%-42,5\%). Namun mengingat RSCM merupakan rumah sakit rujukan nasional maka diharapkan hasil penelitian kami dapat mewakili populasi pediatrik di Indonesia.

Sebagai simpulan insufisiensi adrenal cukup sering dijumpai pada anak sepsis $(26,7 \%)$ dan harus dipertimbangkan khususnya pada syok septik. Penelitian lanjutan diperlukan untuk dapat menentukan efektivitas terapi steroid pada populasi anak.

\section{Daftar pustaka}

1. Venkataraman S, Munoz R, Candido C, Witchel SF. The hypothalamic-pituitary-adrenal axis in critical illness. Rev Endocr Metab Disord. 2007;8:365-73.

2. Marik PE, Zaloga GP. Adrenal insufficiency in the critically ill: a new look at an old problem. Chest. 2002;122:784-96.

3. Reincke M, Allolio B, Wurth G, Winkelmann W. The hypothalamic-pituitary-adrenal axis in critical illness: response to dexamethasone and corticotropin-releasing hormone. J Clin Endocrinol Metab. 1993;77:151-6.

4. Hebbar K, Rigby MR, Felner EI, Easley KA, Fortenberry JD. Neuroendocrine dysfunction in pediatric critical illness. Pediatr Crit Care Med. 2009;10:35-40.

5. Rothwell PM, Udwadia ZF, Lawler PG. Cortisol response to corticotropin and survival in septic shock. Lancet. 1991;337:582-3.

6. Soni A, Pepper GM, Wyrwinski PM. Adrenal insufficiency occurring during septic shock: incidence, outcome, and relationship to peripheral cytokine levels. Am J Med. 1995;98:266-71.

7. Hatherill M, Tibby SM, Hilliard T, Turner C, Murdoch IA. Adrenal insufficiency in septic shock. Arch Dis Child. 1999;80:51-5.

8. Annane D, Sebille V, Troche G, Raphael JC, Gajdos P, Bellisant E. A 3-level prognostic classification in septic shock based on cortisol levels and cortisol response to corticotropin. JAMA. 2000;283:1038-45.

9. Loisa P, Rinne T, Kaukinen S. Adrenocortical function and multiple organ failure in severe sepsis. Acta Anaesthesiol Scand. 2002;4:145-51.

10. Bone M, Diver M, Selby A, Sharples A, Addison M, Clayton P. Assessment of adrenal function in the initial phase of meningococcal disease. Pediatrics. 2002;110:563-9.

11. Menon K, Clarson C. Adrenal function in pediatric critical illness. Pediatr Crit Care Med. 2002;3:112-6.

12. Marik PE, Zaloga GP. Hypotalamic-pituitary-adrenal insufficiency. Crit Care Clin. 2001;17:25-38.

13. Pizarro CF, Troster EJ, Damiani D, Carcillo JA. Absolute and relative adrenal insufficiency in children with septic shock. Crit Care Med. 2005;33:855-9.

14. Sarthi M, Lodhda R, Vivekanandhan S, Arora NK. Adrenal status in children with septic shock using 
low-dose stimulation test. Pediatr Crit Care Med. 2007;8:23-8.

15. De Waele JJ, Hoste EAJ, Baert D. Relative adrenal insufficiency in patients with severe acute pancreatitis. Intensive Care Med. 2007;33:1754-60.

16. Menon K, Ward RE, Lawson ML, Gaboury I, Hutchison JS, Hébert PC, the Canadian Critical Care Trials Group. A prospective multicenter study of adrenal function in critically ill children. Am J Respir Crit Care Med. 2010;182:246-51.

17. Singhi SC. Adrenal insufficiency of criticall illness. Indian Pediatric. 2002;39:1011-6.

18. Casartelli CH, Garcia PCR, Piva JP, Branco RG. Adrenal insufficiency in children with septic shock. J Pediatr (Rio J). 2003;79:169-76.

19. Goldstein B, Giroir Brett, Randolph A, and the Members of the International Consensus Conference on Pediatric Sepsis. International pediatric sepsis consensus conference: definitions for sepsis and organ dysfunction in pediatrics. Pediatr Crit Care Med. 2005;6:2-8.

20. Keh D, Sprung CL. Use of corticosteroid therapy in patients with sepsis and septic shock: an evidence-based review. Crit Care Med. 2004;32:527-33.

21. Bollaert PE, Fieux F, Charpentier C, Levy B. Baseline cortisol levels, cortisol response to corticotrophin, and prognosis in late septic shock. Shock. 2003;19:13-5.

22. Barnes ND, Joseph JM, Atherden SM, Clayton BE. Functional tests of adrenal axis in children with measurement of plasma cortisol by competitive protein binding. Arch Dis Child. 1972;47:66-73.

23. Singhi SC. Adrenal insufficiency in critical ill children: many unanswered questions. Pediatr Crit Care Med. 2002;3:200-1.

24. Kozyra EF, Wax RS, Burry LD. Can $1 \mu$ g of cosyntropin be used to evaluate adrenal insufficiency in critically ill patients? Ann Pharmacother. 2005;39:691-8.

25. Tordjman K, Jaffe A, Trostanetsky Y, Greenman Y, Limor R, Stern N. Low dose (1 microgram) adrenocorticotrophin (ACTH) stimulation as a screening test for impaired hypothalamo-pituitary-adrenal axis function: sensitivity, specificity and accuracy in comparison with the high-dose (250 microgram) test. Clin Endocrinol. 2000;52:633-40.

26. Thaler LM, Blevins LSJ. The low dose $(1 \mu \mathrm{g})$ adrenocorticotropin stimulation test in the evaluation of patients with suspected central adrenal insufficiency. J Clin Endocrinol Metab. 1998;83:2726-9.

27. Cooper MS, Stewart PM. Corticosteroid insufficiency in acutely ill patients. N Engl J Med. 2003;348:727-34.

28. Annane D, Bellissant E, Sebille V, dkk. Impaired pressor sensitivity to noradrenaline in septic shock patients with and without impaired adrenal function reserve. $\mathrm{Br} \mathrm{J}$ Clin Pharmacol. 1998;46:589-97.

29. Zaloga GP. Sepsis-induced adrenal deficiency syndrome. Crit Care Med. 2001;29:688-90

30. Marik PE, Zaloga GP. Adrenal insufficiency during septic shock. Crit Care Med. 2003;31:141-5.

31. Salposky RM, Romero IM, Munck AU. How do glucocorticoids influence stress responses? integrating permissive, suppressive, stimulatory, and preparative actions. Endo Rev. 2000;21:55-89.

32. Schuller JJ, Erve PR, Schumer W. Glucocorticoid effect on hepatic carbohydrates metabolism in the endotoxinshocked monkey. Ann Surg. 1976;183:345-54.

33. Watson S, Carcillo JA, Linde-Zwirble WT, Clermont G, Lidicker J, Angus DC. The epidemiology of severe sepsis in children in the United States. Am J Respir Crit Care Med. 2003;167:695-701. 